\title{
The Impact Of Job Design, Conflict And Workplace Stress On Elementary Theacher's Job Performance
}

\author{
Joseph M J Renwarin \\ Institut Teknologi dan Bisnis Kalbis, Jakarta, Indonesia \\ * Corresponding Author: \\ Email: mrjoseph017@yahoo.com
}

\begin{abstract}
.
This research aims to understand job performance of elementary teachers. This research is a explanatory and evaluative research. The researcher want to know and analyze what are the impact of job design, conflict and stress to job performance. This research samples are 156 respondents with purposive samping method. The researchers use questionnaires disbursement by grouping of area. Data Calculation, For the relationship between two variables and analyze by Statistical Package for the Social Sciences (SPSS) software 22.0 version. All the variables as simultan and together had impact to job performance. Eventhough the results of research is all the variables have influence significants but there are some interesting points of view of this research result.
\end{abstract}

Keywords: Job Performance, Job design, Conflict, Stress.

\section{INTRODUCTION}

Globalization era is the era which requires high competion to survive - especially in the education field. The Indonesian output - graduation could not compete in this era as the result they have lack of skill and academic. It is clearly stated in the research which is conducted by United Nation Development Program called UNDP, 2011 that Indonesia Human Development Index has been insignificantly increasing since 2010.(www.beritasatu.com, 2013). The data describes that in 2010. Indonesia set in 108 out of 185 countries, 2012 in 124 out of 185 and 2103 in 121 out 165. It is left behind from Malyasia and Singapura. The position of Indonesia is till in the low position. The other research which conduted by UNESCO, Programme for International Study Assesment in the South (PISA), 2012, Indonesia is on the last rank in the world (tempo.com,2013).

Referring the data from Education For All (EFA) Global Monitoring Report 2011, the rank of Indonesia is 69 out of 127 countries in the world while the position of Indonesia in Asia is left behind Brunei Darussalam and Malaysia and the newest published, 2012, the rank of Indonesia is 64 out of 127. According to Anandwiwahyuni (www.blog.umy; 2013), the two indicators that could influence the low quality education in Indonesia are the result output of graduation and the low teachers' quality. The result of National Examination Primary School 2012 DKI Jakarta did not show the best result. DKI Jakarta as the capital city in Indonesia and as the standard quality of education in Indonesia only reached in the second position. The best achievement in DKI Jakarta is in South. The following year 2013, the average of score of the DKI is only 22, 99 left behind from Yogyakarta. From the research, it implies that Indonesia graduation is lack of professional. Being professional means the human resources should have good academic and skill to fulfill the need of the global job market.

Achieving the professional graduates who are competence as those above qualifications with two factors are needed - good quality of curriculum (academic and skill) to cope the competitions in globalization and the agent of conducting curriculum itself ; a teacher. The result of this is Teacher Competency Test which conducted on Thursday, August $3^{\text {rd }}, 2012$ shows surprisingly the national average score of Teacher Competency Test in Indonesia is 42,25 and the percentage is $35 \%$. It implies that teachers could only answer 35 numbers out of 100. The worst thing is the national position of DKI Jakarta is in the second under D.I. Yogyakarta with 49.20. This supported by the research which is conducted by Ditjen PMTK 2011. The 
result of teacher quality index in Indonesia is only half from maximum score (11) and also stated by Syawal Gultom, the chief of Education Quality Control and Education of Human Resources Agency, Education Ministry, on March $6^{\text {th }}, 2013$, that the result of teacher competency test is teachers only gained the highest score 80 and even there is 1 . The worst thing of the teachers' quality is on the research by Asian South Pasific Beurau of Adult Education (ASPBAE) and Global Campaign for Education, the aspect of teacher is on the last rank $\left(14^{\text {th }}\right)$ out of 14 countries.

As seen clearly, the teacher is the key and plays important role to success in operating the curriculum which could lead and create the professional and competence output of education (graduates) whose ability to compete the global competition. Implementing the good quality of curriculum requires a professional teacher. There are many perspectives of professional teacher. Daoed Yoesoef $(1980,10)$ stated that being a professional teacher must be able to conduct the three main tasks; professional, human and social tasks. Professional task is a kind of job which is well in delivering the knowledge, the skill and other academic values. Human task is a duty that a teacher encourages and guides the students to find out their identity, their transformation, recognize and understand them. Its aim is to encourage the students to improve their ability of thinking or their logic thinking in order to participate in the culture's transformation actively into a better life in the future. Regarding to Indonesia Government rule number 14, 2015, Teacher as a professional who has the primary task of educating \, teaching, guiding, directing, training, assessing and evaluating students on early childhood, in formal education, primary and secondary. It implies that being a teacher is not only to deliver the knowledge but the teacher also educates and guides the students in order to overcome the problem in future and have the competency which adjustable with the need of job market in the globalization era.

For that purpose, this research is conducted to make evaluate about the variables which will impact on the elementary teacher's job performance. Also, this research try to find the best strategy for develop performance which is will be info to government for increasing the best performance of elementary teacher's.

\section{MATERIALS AND METHOD}

\section{Job Performance}

Job performance comes from two words; Job and Performance. According to Oxford Learner's Dictionary of Current English, the definition of Job is a piece of work, either to be done, or completed while Performance means notable action ; achievement. So that, Job performance is the achievement or notable action from a piece of work, either to be done or completed. Job performance referes to an individual's proficiency with which he or she performs activities which give to the organization's technical target (Sabine et all, 2002 :112). The contribution could be 2 kinds - direct and indirect. Direct contribution refers to in the case of production workers while indirect contribution refers to in the case of managers or staf personnel. Job performance is series of result that is achieved and refers to the action to achieve and also the process of action to gain the goal (Rivai, $2005: 15$ ). It implies that job performane is a goal that is achieved by the employee in completeing the piece of work or the its work should be standarized and fulfil the critearia achieved. Based on the above definition, it could be conclude that job performance is a series of works or tasks that must be fulfilled by the employee in order to achive the certain goal or achievement that has already fixed in certain period by the organization. The performance appraisal is an action or process that is applied by organization to evaluate the job performance.

The job appraisal needs to recognize the feed back from all series of work which is conducted by the employee in organization. If the job appraisal is conducted rightly, the job appraisal could give the important benefit for the empoyee, supervisor and the organization (Rivai :2005:17). Furthermore, the job appraisal is the equipment or a tool to recognize whether the employee has already fufilled the target or goal of organization through the right procedure which is applied by organization. Job appraisal is also to determine the strength or the weekness of the employee. So that, the appraisal could analyze the job performance and give the improvement for the employee. The factors which could be measure of job apprisal has 4 factors or 4 variabels (Danang Sunyoto, 2013: 18). The four variabels are : The characteristics of work, it consists of 
the accuracy of time, the skill and the characteristics in completing job. The quality of work, this variable relates to the delegation of additional jobs which is given manager or principals. The perseverance, it consists of the level of attendance in working and the lateness in working, especially in additional works hours. The behavior, it is the employee's respond or behavior to know the responsibility toward among the colleagues, the head or manager and the level of cooperation in evaluating of tasks.

The effective job appraisal, it needs at least 2 main requirements, namely : 1). The objective criterias to recognize the job appraisal 2). The objectivity in the process of appraisal (Gomes, $2013: 137-145$ ). Some methods to be applied the job appraisal. The methods are : Traditional Method, this is the simple method to recognize the job performance and this method could be applied systematicall and not systematically. Rating scale, employee comparation, check list, free form essay and critical incident. The rating scale is to determine the employee characteristics - innovative, initiative, maturity and the contribution toward the task by the manager. The employee comparation is to determine the job performance by comparing among the employee. The checl list is the method to give suggestions or informationfrom the human resources department.The freeform essay is a kind of method which is used to recognize the job performance by writing the all behaviour, action and the personality of the employee for certain time in the form essay. The critical Incident is a method to determine the job performance by observing the all behaviour and action of the employee such as initiative, coorparation and the safety in the certain book. Modern Method, the is development method from traditonal method. Assement Centre, Management By Objective $(\mathrm{MBO}=\mathrm{MBS})$, and Huaman Asset Hunting. Assesment Center is a method which creates the certain examiner team. The certain examiner team consits of the combination examiners both from inside or outside the organization. Management By Objective $(\mathrm{MBO}=\mathrm{MBS})$ describes the method that involve the employee to form the formulation of job appraisal and decide the problem. Human asset accounting is method to recognize the factor of individu as the longer capital or as human resource.

This method is applied by comparing the variabels which can support and contribute in the achievement of the organization's goal. The benefits of job are as follow : The improvement of job performance, the organization, managers or principals could give the feed back employee or teachers with what have achieved in completing the tasks given. The adjustment reward or compensation, the result of job performance appraisal is as the benchmark on taking the decision of giving the employee's or teacher's reward or compensation such as the salary. The decision of job design, the track record of job performance appraisal is also as the benchmark in giving the employee's promotion, mutation, and demotion or relegation. The needs training and development, ss knowing the job performance is low, the manager could take the decision of the needs of training to improve or explore the employee's job performance. The career development, the job performance appraisal is to convince the manager or principal in supporting the employee for career development. This could ensure the organization's effectiveness (Hani Handoko, 1995 : 135). There are two objective of job performance appraisal in the institutional. Firstly, it is the objective for institutional itself - namely (1) the organization or institutional could recognize the weakness of the employee which needs of coaching, (2) the result of job performance appraisal is used to be as a benchmark of the organization or institutional in placement of the employee as adjust with their capability and the objective, and the last (3) it could make easier in deciding the needs of training or coaching. Secondly, for the employee, the result of job appraisal is to create the good climate of working in organization or institutional which could guarantee the legal certainty, to encourage the employee to work more effective and innovative and the last is to discipline the employee in many aspects of working, whether there is the manager or the principal.

\section{Job Design}

Early work on the topic of job design focused on the effects of simplified, standardized jobs and demonstrated that employees often exhibited counter-productive behaviors in response to such jobs. Herzberg and other scholars addressed these issues and argued that employees would actually be more productive and satisfied if their jobs were enriched versus simplified. Later research extended and refined Herzberg's ideas and focused on several specific job properties (e.g., autonomy, feedback) expected to boost employees' motivation, satisfaction and work effectiveness, and the possibility that there were individual 
differences in how employees responded to such properties (Oldham and Yitzhak, 2016). Human resource is the primary subject in the working field. The job performance is determined by the capability of human resource in conducting the job efficiently and effectively through job design. Every organizations include schools has own way to design and arrange the job among the employees ( teachers). The differences of the job design between the employees in the common organizations and teacher in the schools is teacher has the primary job that is called - the main job (in bahasa means tupoksi-tugas pokok guru) and the additional job while the employees in the organizations have different job description which is based on the department. The point to be pay attention in designing and arranging the job in order to have job efficently and effetively must communicate between the leader and the employee - in case is between principal and teachers.

Job design is the arrangement or rearrangement of job in which purpose to achieve the productivity of working level and reduce the job dissatisfaction (Sharma: 2011;). Furthermore, Gibson et al (1997: in Ardana et al; $2009: 160$ ) described that job design is the process of manager in deciding the employee's task and employee's right. Indriyo Gitosudarmo Sudita (1997: in Ardana Komang et al; 2009:160) stated that job design has the relationship with determining the job structure relationship and the individual relationship to establish the variety of job, the responsibility of job and the autonomy of job. It means that job design has play important role to increase or reduce of the job performance. Job design is the function of determination of employee's working in the certain organization or individual (Cadiz et all, 2019). This definition is supported by Robins and Coulter, 2004: in Anang K et al: 2009:160 - stated that job design refers to the task process which are combined to create the completed job. The job design has the aim to form the clear job description so that it could motivate the employee in the successful completion of task. Besides, the aim of the job design is to ensure the employees in recognizing the work place and duties. Therefore, they could work efficiently and effectively to achieve the aim of organization.

Having the good performance, the employees are able to face the challenge associated with employing a large number people in large capacities. Based on business dictionary stated that job design is a kind of work arrangement (or rearrrengement) which is purposed at reducing or overcoming job dissatifaction and employee alienation arising from repetitive and mechanism taks. It implies through job design , company or school is able to try to raise productivity levels by offering non-monetary reward. Based on the above definition, the researcher could summarize that job design has important role to support the job perforrmance. The good job design would lead the employee having good or statisfied job performance while the bad job design would result the low or low job performance. It means when the employee has statisfied job design, the employee could complete the task efficiently and systematically. In the other hand, the bad job design could lead to reduce the job performance.

The employee could not fulfill the task punctully. The dimensions in this research based on Skill variety, the skill variety is associated with the capability of the human resources to conduct the job. This will lead the employee to stay longer in their works but the negative things are able to result the low job performance. It is because the employee could work efficiently. Task Identity, the amount of task will deliver; it should recognize the time allocation, the human capability, and other constants. Deeper understanding the time target will match the employee's capability in the purpose to have high job performance. Task Significance, the task significance refers to know how various functions or components or tasks are carried out to the other mission. Being knowing the importance of the task, the employees (teachers) would work better. Further more, by giving the clear and certain the task, the employee would work efficently and it will support the solid of organization or school's team work. Autonomy, the autonomy describes the degree of the employee control the performance of task. Feedback, it is the direct response to the activity performed in the interaction of the organization.

\section{The Strategy of Job Redesign}

Job redesign strategy is the process of the manager who reconsiders what the employee expected to conduct the job. There are three strategies in the redesign of the job (Ivanceich et al, $2005: 219$ ), those are : Job Simplification, the job would be simplified as to minimize the time allotment, improve the employee's skill and to minimize the tools. Job Enlargement, the job enlargement is to increase the amount or the various of job. Job Enrichment, the last strategy is to enrich and improve the job vertically. The manager or principal 
has the important role to encourage the employees' or teachers' job performances by designing the job. The good job design will lead the employee complete the task efficiently and fulfill the target. It means the employee has statisfy performance or good performance in working. The bad job design will lead the employee finds the difficulty in completing the job and will also take longer time to complete the work. As a result, the employee perform low in job. Good design should incoparate the relationship with organizational goals and values well. Therefore, the manager should describe what task are done, when and how the tasks are done, in what order affect the work and organizations of the contents and tasks. The good job design should fulfill 5 characteristics, namely :

1. The job design could encourage the employee to apply the best and various capability to conduct the job. It is because when the employee only apply one capabily and stay in one place continously, it will make them bored and they could not develop their capability.

2. Delivering the job to the employee must determine the employee's capability to fulfill the time target (time allocation). It means the capability of employee could handle the time target which is fixed.

3. The employee must know the importance of their task. Having knowing the importance of task, it will encourage them to complete the task effieciently and systematically and led them to manage the priority of works.

4. Giving the responsibility of the task, the employee could control the performance of work. It implies the employee would complete the task responsibility. Furthermore, the high responsibility in completing the task given will lead the high employee's job performances.

5. Feedback of the task should be given to evaluate the job performance. The positive feedback describes the high performances, the negative feedback implies there are something should be revise or fix in job design.

The job resources of job autonomy, task feedback, and task significance are expected to have a positive linear effect on affective commitment. Jobs with low autonomy require employees to follow rigid rules and procedures and provide little flexibility for employees to structure work according to their circumstances and preferences. This implies that increasing job autonomy facilitates the development of affective on job performance (Pee and Lee, 2015). Based on the point before, in this research, the author make the hypothesis as follows;

\section{H1. There is impact between Job design on Job Performance.}

\section{Conflict}

Conflict is possibly happened in every organization, including the school as the formal institution where the individuals interact within. The conflict is like the other assets of organization which has capability to destroy or improve the organization. All individuals in the certain organization should realize the existence of conflict. The conflict could not be avoided in behalf of organization. The conflict is one sign that there is different perspective within two or more than the individual or group in the organization. This is as the result of every individual brings their own values, purpose, perspective, and status. Task conflict, as a collective construct (Jehnet al., 2010), results from individual members'conflict perception. Departing from the team-level definition of task conflict, we define individual task conflict as an individual-level perception that reflects a disagreement between a focal member and other members regarding how a team'swork is being performed (Rong et all, 2018). Conflict is the process when one individual or party or group (A) tries to counterbalance the other individual or party or group (B) through interfering with. Therefore, the other individual or party or group (B) frustrated in the achieving of the mission or target. The condition where there is negative atmosphere within individuals or groups who are not one mission to achieve the target or the aim of organization and gives the opportunity to interfere their achievement (Li C-Rong et all, 2018). Conflict is a negative competition which is declared clearly and directly in order to interfere in achieving the targets or mission. The inferences could be passive and active efforts. Conflict could be derived into 3 visions - namely Traditional Vision, Behavior Visions and Interaction Vision. Conflict as tradition conflict is the negative conflict. It is because it shows there is mistake in one organization and it is dangerous conflict which could destroy the institutional (Sunyoto, 2013: 30 -34). The second vision of conflict stated 
that this conflict happens in one institutional like school. This could also lead to the negative (dysfunctional) and positive (functional) conflict. It is because the members of the institutional are unique since they come from the different background, different interest and understanding. The last conflict determined that conflict could not avoid within the members interaction in one institutional which has already set up the job design. This conflict could also lead to the negative and positive conflict. In this vision, the important point is the manager or principal should manage this conflict among the members within interaction in order to lead the functional conflict which could make the members working innovative and efficiently. From the above definitions, it could be concludes that conflict often arises because there is misunderstanding, misconception in the shared of the needs or the expectation and the values or perspective to the others. Therefore, the conflict arises in the organization. The conflict could be lead into dysfunctional and functional conflict. It depends how to manage the conflict. The Conflict could divide into three dimensions based on the agents of conflicts - Intra personal Conflict that happens in the individual, Interpersonal Conflict which is the conflict arises between two individuals or more than and Organizational Conflict. (InWent, 2004, rewrite by Soemarman, 2013 : 12). The intra personal conflict is conflict that arises inside the individual. The interpersonal is possibly happened because there is different point of view, different attitudes and different role of individual. The different point of is caused as the reflection of how the individual thinking or perspective to respond the event or case while the different attitudes is caused by the different of values of life the individual conveys and believe. The last, the different role of individual is caused by the boundaries and demands from the organization. According to Stoner in Suzy Widyasari (1999:48), the organizational conflict is disagreement between two or more organization members or group arising from the fact that they have different statues, goals, values or perception. It implies that this conflict arises because there is different opinion or perspective within two more than members of organization or two organizations or more. The types of conflict depending on the quality of conflict are dysfunctional conflict and functional conflict. The dysfunctional conflict is destructive conflict. It means it could destroy the system of group's job performance. It arises the negative competition to achieve the target and the inferences in conducting the job. It can cause the low job performance. The functional conflict is the constructive conflict. This conflict is able to support the mission of group in achieving the goal, repair and improve the job performance.

\section{The Correlation of Conflict and Job Performance}

Common point of view stated that conflict conveys the negative correlation toward the individual's or organizational job performance. This misleading opinion could be broken down as in fact that the right treatment of conflict brings the positive correlation toward the job performance, as the shown in the table.

Tabel 1. The Correlation of Conflict and Job Performance

\begin{tabular}{lllll}
\hline \hline Condition & $\begin{array}{l}\text { Level of } \\
\text { Conflict }\end{array}$ & Characteristics of behavior & Dimension & $\begin{array}{l}\text { Job } \\
\text { performanc } \\
\mathrm{e}\end{array}$ \\
\hline A & Low & $\begin{array}{l}\text { Apathetic, stagnate, Passive, } \\
\text { lack of idea }\end{array}$ & $\begin{array}{l}\text { Dysfunction } \\
\text { al }\end{array}$ & Low \\
\hline B & Optimal & Innovative, motivation & Functional & High \\
\hline C & High & $\begin{array}{l}\text { Unorganized, no cooperation, } \\
\text { no coordination }\end{array}$ & $\begin{array}{l}\text { Dysfunction } \\
\text { al }\end{array}$ & Low \\
Source : Ivancevich.et.al: 2005:Organizational and Culture Behavior; Second Edition: $p 45$ & &
\end{tabular}

\section{Stimulus Conflict Methods}

The purpose of the stimulus conflict method is to arise the functional conflict in organization. It encourages the individual to be more innovative, creative, high performance. The reason is because the level of conflict is low which could put the employee in comfort zone. It is dangerous as they do not have a spirit of competition in performance to achieve the goal. The stimulus conflict concludes (1) implantation of outsider into the organization, (2) job redesign, (3) reward system, (4) the right and adjusted leader selection, 
and (5) the uncommon treatment. The purpose of the reduction conflict method is to decrease the dysfunctional conflict which could lead the destruction. According to Indriyo Gitosudarmo and Sudita (Schepers JJL et all, 2018), there are methods to reduce this conflict. The first is Ignoring methods. It explains that it must not look for the root causes. Ignoring and physically separation are the steps in this method. The second, the interference dominance methods is used when the groups which are in the conflict are not able to solve the conflict. The steps are (1) applying the authoritarian command and the rules (2) political maneuver that is gathering the power to insist the other groups. The third, deflated method is to reduce the surface tension of the conflict without touching the base problem of the conflict. The steps are (1) soften the atmosphere. Meaning to say, the conflict groups give priority to togetherness, (2) compromise , (4) identify the enemy. The fourth, resolution method is to identify the problem and to endeavor the source or the base of the conflict. In this research, the author make hypothesis as follows :

\section{H2. There is impact between Conflict on Job Performance.}

\section{Stress}

Human being as an individual is social creature. It simply explains that every individual could not live alone. He/ she must interact with the other individual and the surroundings. During the interaction, an individual has experienced under pressure as we are known stress. The level of stress starts from the low level until the heavy level - called depression. Stress is the adaptive reaction, which shows the special individual characteristics and or as the consequences of certain action, condition, incrediable events whish needs the individual's physical and or psychologist force (Kreither and Kinicki, 2001:587). Szilogyi defined stress is an internal understanding which creates the unbalanced of the individual's physical and psychological condition as the consequences of external environment, and the organizations. Mikhail stated stress is arose form of the unbalanced demand, both reality and or what the individual feel inside his/her soul. Djanaid explained that a good physical emotion response and cognitive towards the certain individual's demand . (Ardana Komang et.al; 2009 : 24-25) Working stress is described as stimulus, respond and respond-stimolous (Gibson et al, 2000:9). It is explained that stress is as stimulus that put the focus on the environment. It means that stress is as the consequence between stimulus environment and the individual respond. Luthans determined stress as a respond for adjusting toward the changing which is infuenced by the differences personal individu and the psychological process, as the consequence from the environment act, the situatin or the events which need the psychological demand and physical individu (Yulianti, 2000:10). Seeing the above definition, the stress relates to the individual performance. It could not neglect as the important role in creating the job performance in the social life.

The source of stress which is well known as - Job stressor is very various and every person has own and different responds to the job stressor.The stress in working place could be driven from many aspects of the environment attached - as follows (Danang Sunyoto, $2013: 42$ - 44) : Internal factors, the internal factor could cause the individual stress as this factor is determined by the personality, ability and cultural values. The personality is the psychological system which belongs to the individual to interact among the other individual or the environment. This personality factor is determined by hereditary, environment, situational, and the individual characteristics. The ability factor describes the capacity of individual in conducting or completing the tasks in one job design. This is determined by the physical ability and intellectual. The cultural values consists of the individual's belief or influenced by social environment which affects to individual's the attitude and behavior. Organization/External factors, there are alot of factors in the organization that arise stress. The factors that can allow the stress as follows : The intrinsic factors which are attached in the job, the job demand that lead the employee's stress like job design(the task variety, the autonomy task), the condtion of job and the chain of working.

The more task variety tends to gain the higher stress to the employee. The more relationship in doing one task will increase the high stress for the employee. In the other way, the autonomy will tend to reduce the stress of employee. The relationship among the individual among in organization or between organizations, this consists of role conflict which could lead the individual in the certain conditions like (1) the contradiction between the demand in completing the tasks and the responsibility in completing the tasks; (2) the tasks which are completed are not part of the responsibility; (3) the demands from the head, the 
subordinate, the colleagues or the individual who considers important to the employee and (4) the contradiction of values and the belief. These would lead the uncertainly and unclearly the individual's position in the organization like school so the span of control is less. The organization's treatment of individual like the factor of career development which the dissatisfaction of career development, the late promotion. The structure of job, the climates of job, the job design in the organization. The leadership style.

The positive or the negative respond to the stress depend on the personality or characteristics of the employee.The diffrences like point of view, the working experiences, the social support from the colleagues and the competion among the employee will influence each other factors. The correlation of Stress and Job Performance describes as inverted. If the level of stress is low, the job performance is low. In this condition, there is no challenge and will lead the boredom. The employee would not produce the creativity and innovative in completing the job. It is because of under stimulation. As the increasing of stress level, it will reach on the optimal stress or functional stress. In this case, the optimal stress could create the innovative idea, enthusiasm of working and the constructive output. In the high level of stress, it leads also the low job performance. In this condition, the stress decreases the quality of job performance.

The excessive stress causes the under pressing of the employees and they could not adequate to complete the tasks. This stress should be managed into the functional stress which could lead high job performance (Danang Sunyoto, $2013: 44$ ). As the stress is related to the individual's emotion, it can be affected to : Physical Effect such as arising the blood pressure, arising the cholesterol, heart attack. Psychological Effect could be drawn in the symptoms the percentage of the attendance, feeling depressed, not confidence, easily angry, confusing, nervous and sad, easily misunderstanding, spiritless, difficulty in consentration, taking the decision, loosing the interest in any kinds of aspect, creativity. Organization/ Behavior Effect such as the percentage of the attendance, the low working statisfaction, the decreasing job performance, loosing the spririt of working and energy, disable communicate well, taking the bad decision, decreasing creativity and innovation, the low productivity in working, resign from the job. In this research, the author make hypothesis as follows :

\section{H3. There is impact between Stress on Job Performance.}

\section{Research Method}

The research would focus on the problems of the factors which can influence of the job performance specially teacher's job performance in order to improve the quality of the teacher in preparing the students to be a job seeker who is competence in competing and challenging the globalization. The factors - like motivation, stress, conflict, the job design, the style of leadership are possible to influence the teacher's job performance. In this case, the researcher would pay attention on the job design, the stress and the conflicts of job of the factors which would be researched. Elementary teachers are the object of the research as elementary teachers are the foundation or the base of education system in Indonesia. They play very important role in laying down the basic knowledge and characters of the students. Because there are the thousands of elementary teachers in Jakarta, the researcher only concerns the research in the elementary teacher in district of Kebonjeruk, West Jakarta. The research is conducted at Elementary Schools which are located in district of Kebunjeruk, West Jakarta. Elementary schools in Kebon jeruk are 91 schools both states and privates schools which spreads in 6 villages - namely Duri Kepa, Kebon Jeruk, Kedoya Utara, Kelapa dua, Sukabumi Utara and Sukabumi Selatan (www.datadikdki.net,2013). Since the areas of Kebon Jeruk is large area, the researcher conducts the sample schools that are located in 2 areas which are Kebon jeruk and Duri kepa.

Regarding the above theoretical review, the job design, conflict and stress are the independent variables which have correlation toward the dependent variable - job performance. The correlation of the independent and dependent variables are the same direction variables. It implies that dependent variable - the problem of the research is caused by the independent variables - the root/ base problem of the research. The technique is to identify the degree of influence toward Independent variables, which are Job Design $\left(\mathrm{X}_{1}\right)$, Conflict $\left(\mathrm{X}_{2}\right)$, Stress $\left(\mathrm{X}_{3}\right)$ and Dependent variable, which is Teachers' Job performance $(\mathrm{Y})$.

The influence among these variables could be represented in the form constellation as drawn below : 


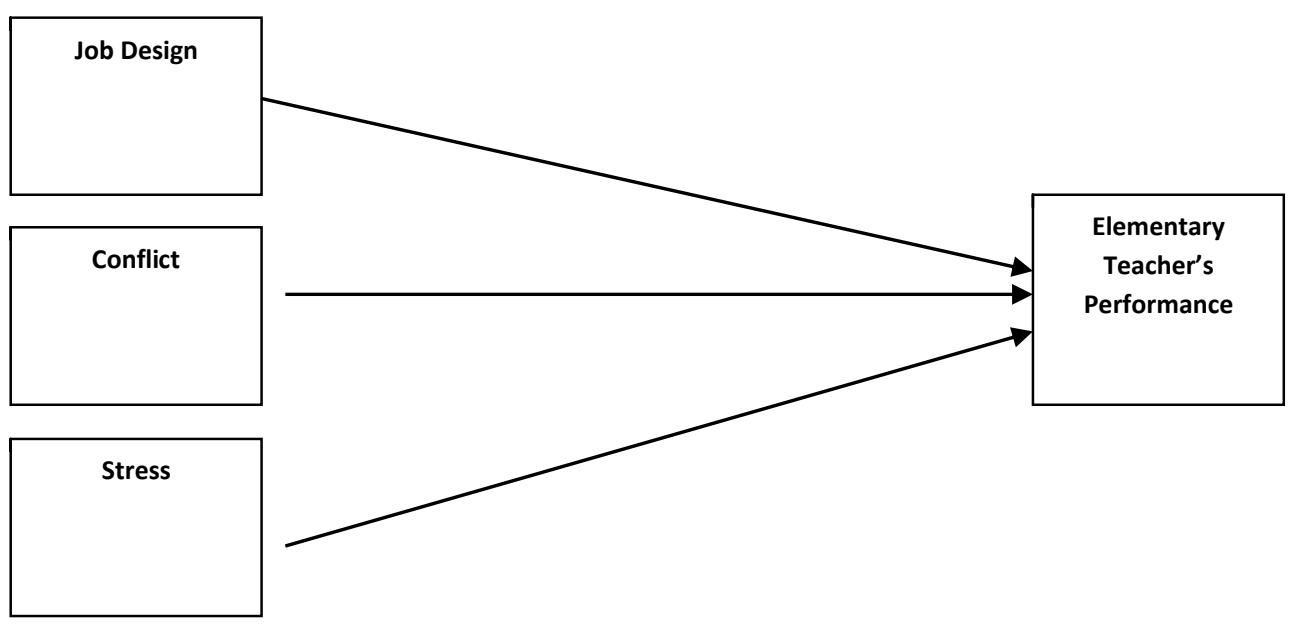

Research can be described as a systematic and organized effort to investigate the specific problem that needs a solution (Sekaran, 2013: 4). Research is applied the data-based, critical, scientific inquiry or investigation into a specific question or problem with the purpose of finding answers or problems. According to Oxford Advanced Learner's Dictionary of Current English, research defines an investigation which is conducted in order to recognize new facts or find out additional information. It means when the researchers conduct the reseach, they have conducted step by step orderly to search the new facts or extra informations. Research could be driven into four types different purpose - Quantitative Method and Qualitative Method. The Quantitative Method - also known as Positivistics Method is the method which focuses to investigate the result of its finding to solving specific problem currently being happened in the organization by undertaken scientific way, empirically, rationally and systematically in certain population or samples.

There are two types method in the quantitative method - Survey and Experiment Method. The survey method defines the survey method design provide a plan for quantitative or numeric description of trend, attitudes, or opinions of population by studying a sample of that population. (Kerlinger:1973). While the experiment method, it seeks to recognize if a certain treatment influence the outcome in a study. The result is assessed by providing a certain treatment to one group and with hold on if from other group. After that it would determine how both groups score on an out put. (Creswell:2012:36). These schools are Sekolah Dasar Negeri Duri Kepa 07 Pagi, Sekolah Dasar Negeri Duri Kepa 08 Pagi, Sekolah Dasar Negeri 16 Pagi, Sekolah Dasar Negeri 17 Pagi, Sekolah Dasar Negeri Kebon Jeruk 01 Pagi, Sekolah Dasar Negeri Kebon Jeruk 02 Pagi, Sekolah Dasar Negeri Kebon Jeruk 04 Pagi, Sekolah Dasar Negeri Kebon Jeruk 05 Pagi, Sekolah Dasar Negeri Kebon Jeruk 06 Pagi, Sekolah Dasar Negeri Kebon Jeruk 07 Pagi, Sekolah Dasar Negeri Kebon Jeruk 08 Pagi, Sekolah Dasar Negeri Kebon Jeruk 10 Pagi, Sekolah Dasar Negeri Kebon Jeruk 11 Pagi, Sekolah Dasar Negeri Kebon Jeruk 12 Pagi, Sekolah Dasar Negeri Kebon Jeruk 15 Pagi, Sekolah Dasar Negeri Kebon Jeruk 16 Pagi, Sekolah Dasar Swasta Santo Andreas, Sekolah Dasar Swasta Rasa Sayang, Sekolah Dasar Swasta Widuri Jaya,dan Sekolah Dasar Swasta Pelita II.

The Population describes a group or all elements of people, events or things of interest that are going to be observed by the researcher (Sekaran, 2013; 225). In this research, the researcher is going to observe the 263 populations which spreads in 2 villages in Kebon jeruk. Due to the amount of the elementary teachers in the district of Kebonjeruk 1.322 teachers, the researcher is going to choose some of them as the sample of the object research. Sample is the subset of population. It means that the amount of populations is comprised into the representative populations. The reason are to minimize the deviation, able to predict the condition of the population, and inform the condition of population efficiency and effectively. The other reason of using sample is there is a certain research which could not use the population. So that, the sampling gives the reliable result if it is comparing with collecting data from the population. There are two types method of taking sampling - Probability Sampling and Non-probability Sampling. In this research, the writer will apply the Non-probability Sampling. It is the technique which sample subjects are the elements that do not have any probability attached to their being chosen. The Quota Sampling is applied in the research. The reason of application of this method is to avoid the homogenous to determine the amount of the sample which is 
representatives; the writer would account the formulation of the minimum requirement of sample (Sekaran; 2013: 225-240). The population in this reserach is 263 elementary teachers in district Kebon Jeruk. From these population, the writer could determine and use 159 teachers as sample.

\section{RESEARCH RESULT AND DISCUSSION}

The descriptive statistics are used to identify the clear description or characteristics of the Job Design, Conflict and Stress datas which are applied to test the influence toward the Job Performance.

Table 2. Result of Descriptive Statistics Test

\begin{tabular}{|c|c|c|c|c|c|}
\hline \multicolumn{6}{|c|}{ Descriptive Statistics } \\
\hline & $\mathrm{N}$ & Minimum & Maximum & Mean & Std. Deviation \\
\hline Job Design & 159 & 2 & 5 & 3.65 & .711 \\
\hline Conflict & 159 & 2 & 3 & 2.74 & .442 \\
\hline Stress & 159 & 2 & 5 & 3.34 & .683 \\
\hline Job Performance & 159 & 2 & 4 & 3.25 & .644 \\
\hline
\end{tabular}

Sources : Author 2018

The result could be shown as follows :

- On the indicator measurement of the average value (mean) of Job design that involves 159 population, it is gained 3.65 which has the minimum score is 2 and maximum is 5 . The score is taken from the respondents by using Likert Scale which describes score 1 into 5. Score 1 indicates very disagree while score 5 indicates very agree. If the mean value is 3.65 , it indicates that the respondents' answers tend to agree. It could have meaning that the respondents state almost agree with Job design. The standard deviation of respondents' answers toward the Job Design is 0.711 .

- According to the Job Design's questions, the question which has the higest level of disagreement is Task Identity dimension. It is $32(20.1 \%)$ respondents which stated disagreement to Task Identity dimension in the Job Design.

- On the indicator measurement of the average value (mean) of Conflict, it is gained 2.74 which has minimum score is 2 and maximum score is 3 . The average values of 2.74 describes that the respondents' answers toward the statements state doubt. It means that the respondents express doubt on the exist Conflict. The standard deviation of respondents' answers toward mean Conflict is 0.442 .

- Based on the Conflict's questions, the question which has the higest level of disagreement is Intragroup dimension. It is $54(34 \%)$ respondents which stated disagreement to Task Intragroup dimension in the Conflict.

- On the indicator measurement of the average value (mean) of Stress, it is gained 2.74 which has minimum score is 2 and maximum score is 5. The average values of 2.74 describes that the respondents' answers toward the statements tends to doubt. It means that the respondents express doubt on the exist Stress. The standard deviation of respondents' answers toward mean Stress is 0.683.

- According to the Stress' questions, the question which has the higest level of disagreement is Leadership style dimension. It is $25(15.7 \%)$ respondents which stated disagreement to Leadership style dimension in the Stress.

- On the indicator measurement of the average value (mean) of Job Performance, it is gained 3.25 which has minimum score is 2 and maximum score is 5 . The average values of 3.25 describes that the respondents' answers toward the statements tends to doubt. It means that the respondents express doubt on the exist Job Performance. The standard deviation of respondents' answers toward mean Job Performance is 0.644 . 
- According to the Job Performance's questions, the question which has the higest level of disagreement is Effectively and Efficiency dimension. It is $21(13.2 \%)$ respondents which stated doubt to Effectively and Efficiency dimension in the Job Performance.

The correlation values for 25 indicators which is used to determine the Job Performance variables are Valid and all of them fulfill the validity requirements. It is because it has $r_{\text {count }}>r_{\text {table }}\left(r_{\text {count }}>0.156\right)$. The test result toward 159 respondent, the Cronbach's Alpha coefficient of Job design is 0.904, Conflict is 0.832 , Stress is 0.941 and Job Performance is 0.969 . All of them are stated Reliable, it is because these fulfill the minimal requirement of Cronbach's Alpha coefficient is that more than 0.060 . These values indicate that all indicators being used have the accuracy, high stability or consistency. The result of multicollinerity test from each independent variables is obtained that the tolerance values for the three independent variables are 0.837 for Job Design, 0.865 for Conflict, and 0.830 for Stress. These independent variables have the tolerance value $>0.01$. It shows that within Job Design, Conflict and Stress do not correlate each other. In other words, there is no Multicollinerity in this regression. While the value of VIF for the three independent variables are 1.195 for Job Design, 1.156 for Conflict, and 1.204 for Stress, it means all of them is under the value 10. It shows that within Job Design, Conflict and Stress do not have correlation or there is no Multicollinerity in this regression.

From the output result of SPSS, the value of $t_{\text {count }}$ of Job Design is 9.116. Obtain the value $t_{\text {table }}$ for $\alpha$ $=0.05$, the disttribution table of $\mathrm{t}$ which is calculated on $\mathrm{a}=5 \%$; with the dregree of freedom $(\mathrm{df})=\mathrm{nk}-1$ or $\mathrm{df}=$ $159-1-1=157$ ( $\mathrm{n}$ is the amount of case and $\mathrm{k}$ is the amount of independent variables, is obtained $\mathrm{t}_{\text {table }}=1.975$. The rule of decision is if $t_{\text {count }}>t_{\text {table, }}, H_{0}$ is rejected or significant. The value $t_{\text {count }}$ of independent variable which is applied $>t_{t a b l e}(9.116>1.975)$, it means $H_{0}$ is rejected and accepts $H_{1}$. It means there is significant influence between Job Design toward Job Performance. The equation of linear regression can be formulated as follows : Job Performance $=\mathbf{3 4 . 4 0 5}+\mathbf{0 . 6 9 4}$ Job Design, the constant which is 34.405 has a meaning that if the value of Job design is 0 , the value of Job Performance is 34.045. The regression describes that Job Performance is influenced by Conflict. By result 0.705 means there is amount of influence and supporting of Conflict toward Job Performance is 0.705 . The equation of Linear Regression can be formulated as follows : Job Performance $=\mathbf{2 9 . 2 1 4}+\mathbf{0 . 7 0 5}$ Conflict. The constata 29.214 which is has a meaning that if the value of Conflict is 0 , the value of Job Performance is 29.214. The regression constata of Conflict $\left(\mathrm{X}_{2}\right)$ which is 0.705 states that each 1 unit inchancement of Conflict $\left(\mathrm{X}_{2}\right)$ will increase Job Performance $(\mathrm{Y})$ which is 0.705 and in each 1 unit reduction of Conflict $\left(\mathrm{X}_{2}\right)$ will reduce Job Performance which is 0.705 . The author can know that the high conflict arises but this high conflict supports the high Job performance. It means it is the constructive conflict- functional conflict. This conflict is able to support the mission of group in achieving the goal, repair and improve the job performance. The coefficient result of Stress is 0.580 . It means there is amount of influence and supporting of Stress t Variable $\left(\mathrm{X}_{3}\right)$ toward Job Performance is 0.580 . The equation of Linear Regression can be formulated as follows : Job Performance $=\mathbf{3 9 . 0 3 0}+\mathbf{0 . 5 8 0}$ Stress. High stress appears which is arises in this research support the Job Performance. It means the respondents repond the stress positively. This stress is constructive stress which stimulous the respondents to increase the job performance. The dimention of stress which support the job performance is Working conflict. The simultan test show that the equation of Multiple Regression can be formulated as follows : Job Performance $=\mathbf{- 4 . 4 3 5}$ +0.415 Job design $+\mathbf{0 . 4 5 8}$ Conflict +0.340 Stress. In this regression, show that if the author do not see all variable, there is no performance of elementary teacher's because the constata is -4.435 . The stress is not impact for make strategy because the coefficient score is low.

\section{CONCLUSION AND SUGGESTION}

From the 3 (three) variables, the high significant influence is the Conflict on elementary teacher's Job Performance. The significancy of conflict for the job performance because the high conflict which appears in the working place - dysfunctional conflict usually leads destructive which result the low performance. In this case, the high conflict considers as functional conflict - contrictive which support the mission of group in achieving the goal, repair and improve the job performance. If combine all variables on elementary teacher's 
job performance, there is significant influence among Job design, Conflict, Stress altogether toward Job Performance. It means the Job Design, Conflict and Stress altogether influence Job Performance.

This reserarch is to identify whether Job design, conflict and stress towatd Job Performanc. The suggestion are as hown below :

For school, the stress on Job Performance, it is suggested to school that school should maintance the teacher's stress, It is because it makes the Job performance high. The dimension of stress that is needed to increase is Leadership style. The suggestion steps to increase job performance are :

1. The manager or head master should invite and involve the employees or teachers to decide any kind decission in organization or school.

2. The manager or head master opens widely the opportunity to the employees or teachers in taking the decison or having autonomy of process of working. Furthermore, the employee would feel sense of responsibility and dedication of working. It means it will result higer job perforance.

The Job design on job performance, the school should increase the job design in the dimension of Task Identity. The suggestion steps to increase task identity are:

1. The manager or the head master should opens large opportunity to any employee or teachers to be able to handle any kinds of work by rotating work. It means one person would handle a lot of jobs but the other do not have any kind certain jobs.

2. The manager or the head master should have a good plan or map of working from the baginning of year before he/she delivers the job to the employee/teacher. He/she should also put the border line of working from one to another.

3. As manager or the head master, he/she supports the employee or teacher by giving various tasks not the same tasks for longer period. It would arise the challenging feeling to employees or teachers so they will not get bored.

The Conflict on elementary Job Performance, the school should increase the Conflict in the dimension of Intragroup Conflict. The suggestion steps to maintance intra group conflict are:

1. To reduce the intra group conflict, the manager or head master should create the healthy atmosphere in working place by wise role and clear role.

2. As the manager or head master, he/she should be aware and pay attention on the problems of their employee happens. One way is able to know by doing evaluation or supervison at least once in one semester and the manager or head master conducts weekly or two weekly or monthly meeting to discuss or evaluate the running program or the latest issued or what is happening.

3. Being manager or head master should pay attention in giving the detail instruction to the employee or teacher. Using annual meeting, the manager or head master could delegate the task one a week before and point the person in charge. The aim of choosing person in charge is to help the manager or head master in transferring the instruction.

For the next reserach, the researcher could research on the other aspects which are not observed by this research such as the suitable principle leadership style. So that, this could be as suggestion for school to identify the most important variables in the effort of enhancement Job Performance. This research does not compare Job design, Conflict and Stress among the same level of school. For further researh, this could be conducted the research on the some same level of school with more amount of samples. Therefore, it would be the new findings about job design, conflict and stress which is very infuential toward Job Performance.

\section{REFERENCES}

[1] Ahmad Sudrajat (2010). Teachers' Professionalism. Journal Pendidikan.

[2] Anan wiwahyuni (2013). Penyebab Rendahnya Kualitas Pendidikan di Indonesia (online).:http//www.blog.umy.ac.id/anandwiwahyuni/pendidikan/penyebab-rendahnya kualtas pendidikan-diindonesia.

[3] Ardana Komang,et al .(2009). Perilaku Keorganisasian.2nd ed. Jakarta: Graha Ilmu.Cooper Cary et.al.(1995). Stress Managemen Yang Sukses .Jakarta: Kesain Blank. 
[4] David M. Cadiz, Jennifer R. Rineer and Donald M. Truxillo (2019), Lifespan Perspectives on Joband Work Design. Work Across the Lifespan, P 267-268, DOI:https://doi.org/10.1016/B978-0-12-812756-8.00011-6 Elsevier Inc. All rights reserved.

[5] Don Elger (2010) Theory of Performance. USA : University of Idaho. Access on February 3rd. http://www. University of Idaho.

[6] Greg R. Oldham and Yitzhak Fried (2016), Job design research and theory: Past, present and future. Organizational Behavior and Human Decision Processes Journal. Elsevier Inc. http://dx.doi.org/10.1016/j.obhdp.2016.05.002

[7] Gibson, JL, Ivancevich, J.M et al. (2000).Organization : Behavior Structure and Process. 10th ed. New York : Mc Grow Hill,.

[8] Gomes, Fautisno Cardoso.(2000). Manajemen Sumber Daya Manusia. Jakarta :PT. Andi Offset.

[9] Kasmadi,S.ST, M.Pd et.al.(2014). Panduab Modern Penelitian Kuantitatif : Bacaan Wajib Bagi Peneliti, Guru, dan Mahasiswa Program S1, dan S2 di Lingkungan Pendidikan. Bandung : Alfabeta.

[10] Kreitner,R and Kinichi, A.(2001). Organizational Behavior. 5th ed. New York : Mc Grow Hill,.

[11] L.G. Pee and J. Lee (2015). Intrinsically motivating employees' online knowledge sharing: Understanding the effects of job design. International Journal of Information Management. Elsevier Ltd. http://dx.doi.org/10.1016/j.ijinfomgt.2015.08.00202.

[12] Li C-Rong, Li C-Xuan, Lin C-Ju, (2018). The Effect of IndividualTask Conflict ON Employee Creativity: A Moderated Mediation Model.Thinking Skills and Creativity, https://doi.org/10.1016/j.tsc.2018.11.006

[13] Luthans (1995). Organizational Behavior. New York : Mc Grow Hill.Nasution, Edwin \& Hardius Usman, (2007).Proses Penelitian Kuantitatif. Jakarta: Lembaga Penerbit, Fakultas Ekonomi, Indonesia University.

[14] Pieter, Drucker F. (1997). Introducctory View of Human Performance Technology. San Fransisco: JeossayBass Publisher.

[15] Praptini Yulinati (2013). Pengaruh Sumber - Sumber Stress terhadap Kepuasan Kerja Tenaga Edukatif Tetap Fakultas Ilmu Sosial Universitas Airlangga. Unpublisded Universitas Airlangga. Surabaya accesed on february 3rd, http://www.damandiri.or.id/file/novitasariaddafpus.pdf.

[16] Rivai Veithzal.(2014). Performance Appraisal : Sistem Yang Tepat Untuk Menilai Kinerja Karyawan dan Meningkatkan Daya Saing Perusahaan. $1^{\text {st }}$ edition: PT. Raja Grafindo Persada.

[17] Robbin, S.P. (20011). Organizational Behavior 9th ed. New York : Prentice Hall New Jersey,.

[18] Sri Sukabdiah.(2004). Pengembangan Pembelajaran Implementasi Kurikulum 2004. H. Jakarta.

[19] Schepers, J.J.L., Nijssen, E.J. \& van der Heijden, G.A.H. (2016), Innovation in the frontline: Exploring the relationship between role conflict, ideas for improvement, and employee service performance. International Journal of Research in Marketing, doi:10.1016/j.ijresmar.2016.01.004

[20] Soedijanto (2008). Landasan Dan Arah Pendidikan Nasional Kita. Jakarta: Kompas,.

[21] Soemarno. T .(2013). Conflict Management \& Capacity Building for Personal Development : Mengelola Konflik Untuk Memaksimalkan Produktifitas Kinerja dan Pengembangan. Bandung : PT Elex Media Komputindo Kompas.

[22] Suharsa Umar (2012). Metode Penelitian Kuantitatif, Kualitatif dan Tindakan. Bandung: PT. Rafika Aditama.

[23] Stoner. James A.F \& Charles Wankel (2011). Management. Alih Bahasa; Wilhelmus. Jakarta: Graha Ilmu.

[24] Uno Hamzah (2011). Profesi Kependidikan Solusi dan Referensi di Indonesia. Jakarta: Graha Ilmu.

[25] USAID. (2013).Kilas Balik Dunia Pendidikan Di Indonesia. Jakarta: http//www.prestasiiief.or/index.php/id/feature/68-kilas-balik-dunia-pendidikan-di- indonesia. Accesed September 27th, 2014.

[26] Sabine Sonnentag et al (2002). Psychological Management of Individual Performance. New York : John Wiley \& Sons. Ltd. 